\title{
ANTHOCEROS MACOUNII - A NEW HORNWORT FOR RUSSIAN FLORA
}

\section{ANTHOCEROS MACOUNII - НОВЫЙ ВИД АНТОЦЕРОТОВЫХ ДЛЯ ФЛОРЫ РОССИИ}

\author{
E.A. IGNATOVA ${ }^{1}$, M.S. IGNATOV ${ }^{2} \&$ V.A. BAKALIN ${ }^{3}$ \\ Е.А. ИГНАТОВА ${ }^{1}$, М.С. ИГНАТОВ ${ }^{2}$, В.А. БАКАЛИН ${ }^{3}$
}

Abstract

Anthoceros macounii is found in Primorsky Territory, being the first record of this species in Russia. The species is characterized by a short capsule, 3-6 $\mathrm{mm}$ long, projecting from involucre $2 / 3-5 / 6$ of its length. It is distributed in temperate and subtropical areas of the eastern U.S.A. and Japan.

Резюме

Anthoceros macounii найден в Приморском крае, и это первая российская находка вида, распространенного в умеренных и субтропических районах востока США и Японии. Вид характеризуется короткой коробочкой, 3-6 мм длиной, выступающий из обертки на 2/3-5/6 своей длины.

KEYWORDS: Anthoceros macounii, Anthocerotae, phytogeography, Russian Far East.

Hornworts is one of the smallest divisions of higher plants, including 200-250 species (Villarreal et al., 2010) in the world. Main diversity is in tropics and subtropics, while in the boreal zone the group is poorly represented. In Russia, hornwort flora includes 2 genera and 2(-4) species (Konstantinova et al. 1992; Potemkin \& Sofronova, 2009), composed of widespread Phaeoceros carolinianus (Michx.) Prosk. and Anthoceros agrestis Paton, while two other species are little known and doubtful.

In the course of exploration of Far Eastern bryoflora in Primorsky Territory in October 2006 we found a peculiar hornwort superficially resembling Notothylas due to its small size and capsule shape. The population was revisited also in October, 2008.

The close up study revealed that the species belongs to Anthoceros macounii, the species with the distribution in temperate and subtropical areas of the eastern North America and Asia, and never reported from Russia before.
Anthoceros macounii Howe, Bull. Torrey Bot. Club 25: 19, pl. 326, figs. 1-9. 1898.

Thalli light green, forming compact rosettes $5-10 \mathrm{~mm}$ in diameter, rather strongly lobate, 68-stratose in central part and 2-4-stratose near margins, cavernose on upper surface. Cells polygonal, 30-35×35-75 $\mu \mathrm{m}$, thin-walled. Monoicous. Antheridia by 3-4 per chamber. Involucres shortly cylindrical, to ca. $1 \mathrm{~mm}$ high, not plicate, mouth entire. Capsule cylindrical, rounded at the top, $3-6 \times$ ca. $0.5 \mathrm{~mm}$, projecting from involucre to $2 / 3-5 / 6$ of its length, bivalved, valves rigid at maturity and usually standing upright; valve wall 3-4-stratose. Epidermal cells narrowly rectangular to somewhat irregular in shape, $90-120 \times 18$ $27 \mu \mathrm{m}$; stomata numerous; inner cells with helicoidal bands. Columella 1/2-3/4 of capsule length. Pseudoelaters single, ca. 15-35 $\mu \mathrm{m}$. Spores brown to blackish brown, $42-55 \mu \mathrm{m}$ in diameter, more convex on distal face, quite flat on proximal face that is distinctly trilete, on both faces distinctly and sharply papillose.

1 - Moscow State University, Biological Faculty, Geobotany Dept., Moscow 119991 Russia - Россия 119991 Москва, Московский государственный университет, Биологический факультет, каф. геоботаники; arctoa@ list.ru

2 - Main Botanical Garden of Russian Academy of Sciences, Botanicheskaya 4, Moscow 127276 Russia Россия 127276 Москва, Ботаническая, 4, Главный ботанический сад PAH; misha ignatov@list.ru

3 - Institute of Biology and Soil Science, 100-Letia Vladivostoka Street, 159, Vladivostok 690022 Russia - Россия 690022 Владивосток, просп. 100-летия Владивостока, 159, Биолого-почвенный институт ДВО РАН; v-bak@list.ru 

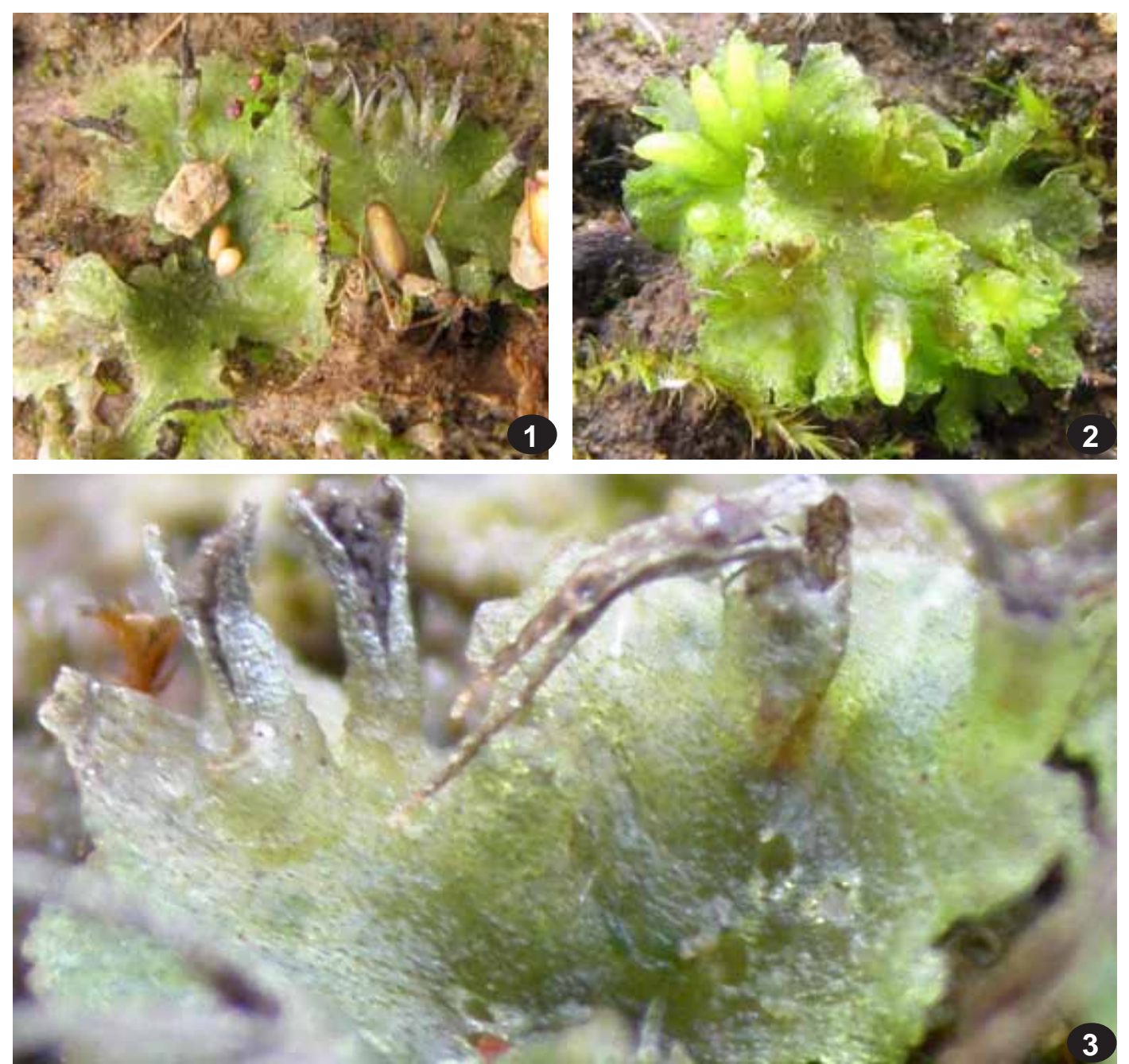

Fig. 1. Anthoceros macounii Howe, photos in nature.

Distribution: eastern North America and Japan (Schuster, 1992; Hasegawa 1984).

Anthoceros macounii was collected on wet clayish ground road in Pinus koraiensis +Picea yezoensis+broad-leaved forest, on October 5, 2006 (after a rather wet summer and early autumn) in several places along ca. $300 \mathrm{~m}$ of the forest ground road, obviously very little used at least that year. On flat places of the road and rut walls along the road a rare liverwort Fossombronia alaskana Steere \& H. Inoue, and mosses: Dicranella varia and $D$. schreberiana were also found.

In 2008 this place was revisited on October 17, and the species was found only after long and extensive search. The year had less precipitation, road was quite dry, and intensively used for heavy log- ging tracks. Anthoceros was found on the road itself, while ruts were mostly flattened by tracks. Only in one spur of road (occasionally used for turns) we found moist and recently disturbed soil banks with Anthoceros, as well as with Fossombronia.

Interestingly, the soil near Anthoceros macounii population had footprints of tiger (Panthera tigris altaica), a rare and vulnerable animal that is able to migrate each day for tens of kilometer.

\section{ACKNOWLEDGEMENTS}

We thank Dr. V.Ya Cherdantseva and Mr. S.-S. Choi for partnership during field trips and the latter also for providing us with his photographs, and Dr. J.C. Villarreal for helpful suggestions on the manuscript. The work of V.A. Bakalin was partly supported by RFBR, 10-04-00050 \&10-04-91150. 

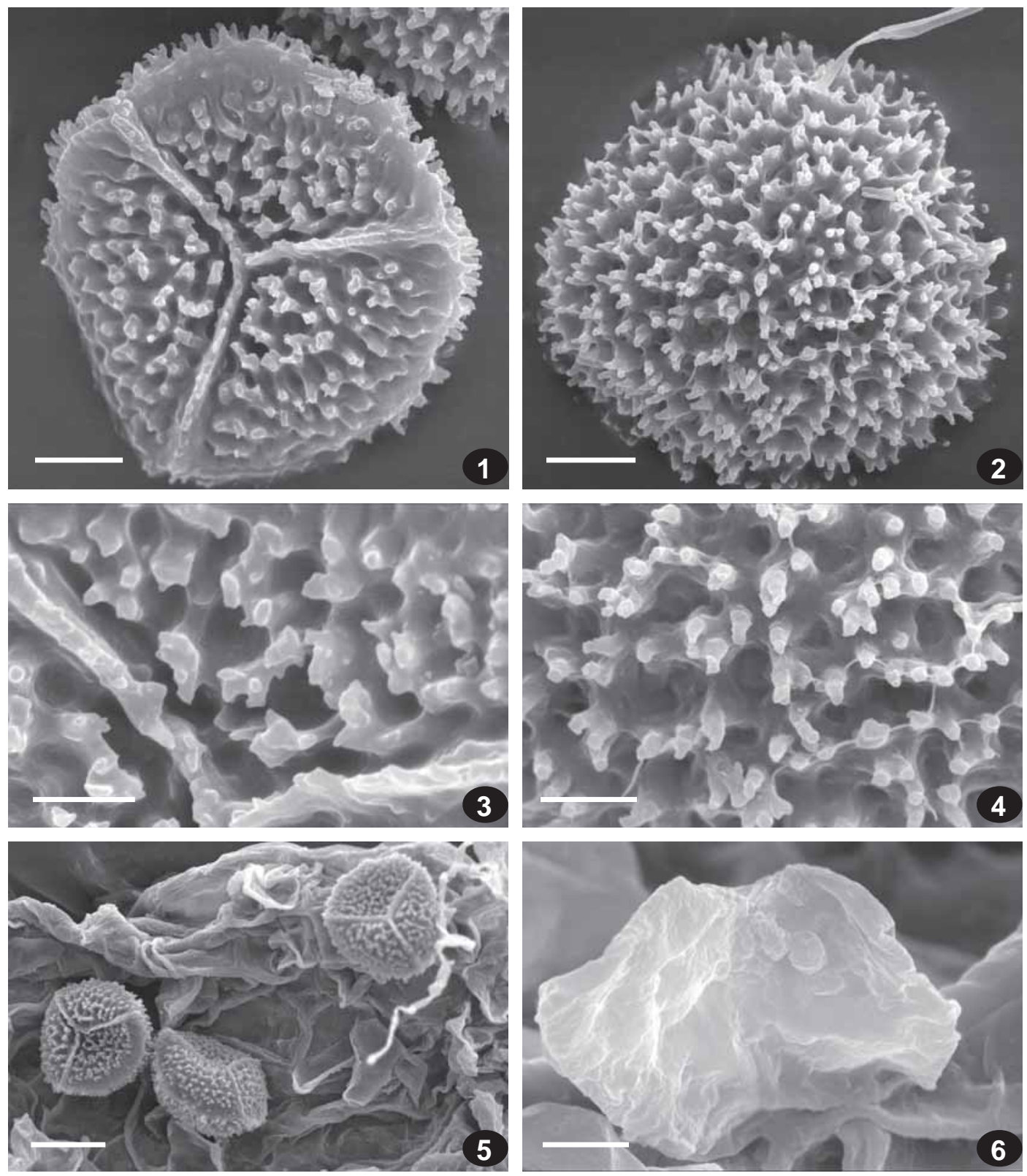

Fig. 2. Anthoceros macounii Howe (from Ignatov \& Bakalin \#08-999, MHA): 1, 3-spores, proximal surface; 2, 4 - spores, distal surface; 5 - spores; 6 - pseudoelater. Scale bars: $30 \mu \mathrm{m}$ for 5, $10 \mu \mathrm{m}$ for 1-2, $5 \mu \mathrm{m}$ for 3-4, 6 .

\section{LITERATURE CITED}

HASEGAWA, J. 1984. Taxonomical studies on Asian Anthocerotae. IV. A revision of the genera Anthoceros, Phaeoceros and Folioceros in Japan. - J. Hattori Bot. Lab. 57: 241-272.

KONSTANTINOVA, N.A., A.D. POTEMKIN \& R.N. SCHLJAKOV 1992. Check-list of the Hepaticae and Anthocerotae of the former USSR. - Arctoa 1: 87-127.

[POTEMKIN, A.D. \& E. V. SOFRONOVA] ПОТЕМКИН А.Д., Е.В. СОФРОНОВА 2009. Печеночники и антоцеротовые России. Том 1. - [Hеpaticae and Anthocerotae of Russia. Vol. 1] СПб и Якутск, Бостон-Спектр [Sankt-Petersburg \& Yakutsk, Boston-Spectr], 368 pp.

SCHUSTER, R.M. 1992. The Hepaticae and Anthocerotae of North America east of the Hundredth meridian. Vol. 6. Natural Field Museum: Chicago: xvii $+937 \mathrm{pp}$.

VILLARREAL, J.C., D. C. CARGILL, A. HAGBORG, L. SÖDERSTRÖM \& K. S. RENZAGLIA 2010. A synthesis of hornwort diversity: Patterns, causes and future work. Phytotaxa 9: 150-166. 


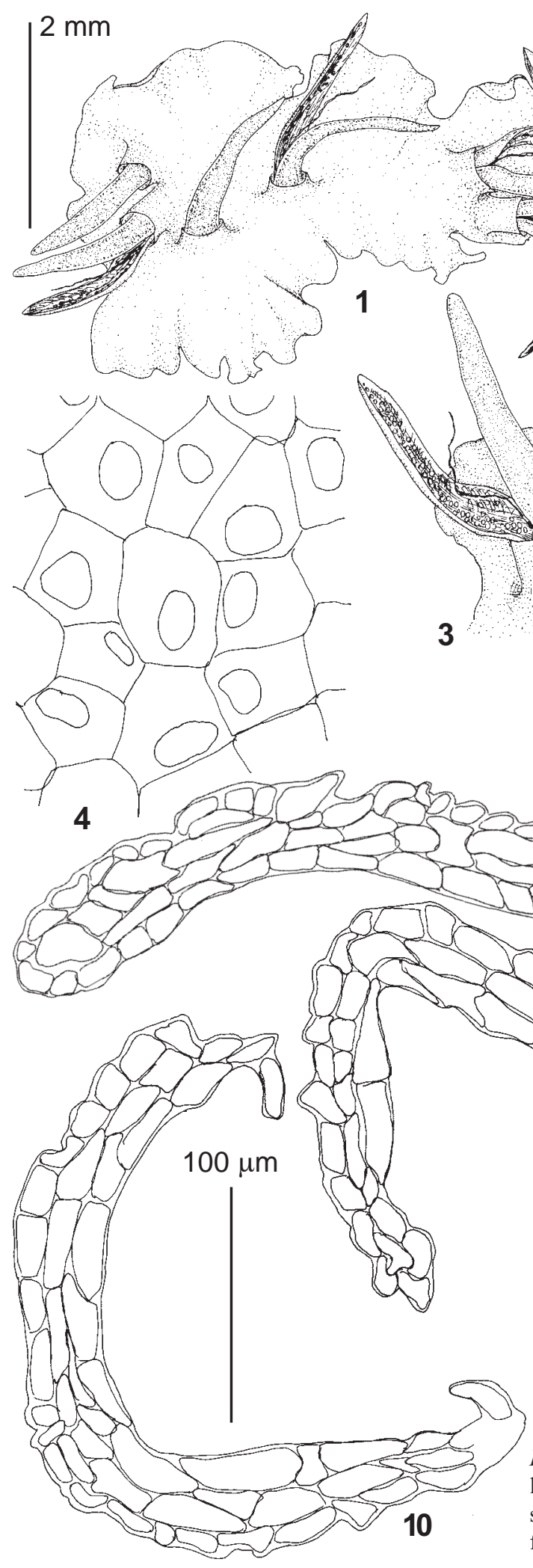

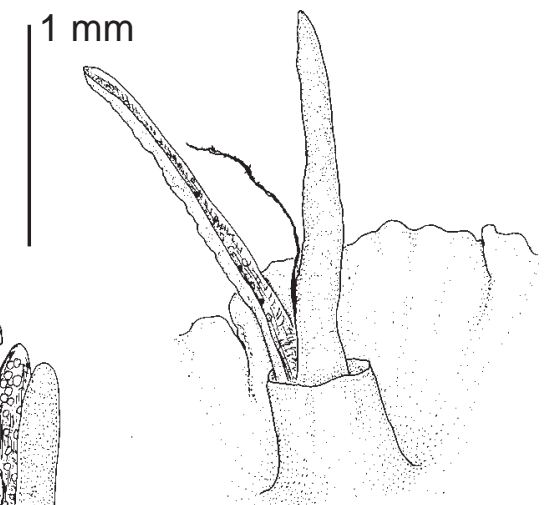

